\title{
TIBF A NOTE: DEBT SELLING AND THEIR IMPACT ON ISLAMIC BANK VALUE ${ }^{1}$
}

\author{
Abdul Ghafar Ismail and Karmila Hanim Kamil \\ Universiti Kebangsaan Malaysia
}

\begin{abstract}
This paper shows how a risk management mechanism through selling debt can affect the value of Islamic banks. Islamic banks are able to maximize their value from the sale of murabahah on housing debt in order to manage their risk arising from fluctuations in interest rates. A tractable theoretical model is developed to maximize the Islamic banks' values from the sale of housing debt financing in order to hedge against fluctuations in interest rates. Our findings showed that Islamic banks could improve their earnings and rectify the problem in aligning their assets and liabilities through the benefits of debt selling. A rise in the market interest rates leads to an increase in the base financing rate and the mark-up rate in Islamic banks, since market interest rates serve as benchmarks in determining profits or mark-ups. If the Islamic banks engage in debt selling to decrease their risk exposure, their earnings or value may be amplified since they have the opportunity to undertake other positive NPV projects from the payoffs on the murabahah debt selling.
\end{abstract}

Keywords: Bank risk management; Financing; Investment JEL classification: G21, G31, G32.

\section{Introduction}

Risk management has become a challenge in Islamic banking because the growth in these banks may not occur without taking risk beyond the norm of conventional banking. Thus, taking additional risk is unavoidable for the Islamic banks to progress. Nevertheless, taking excessive risks will hurt investment and may deter future growth. Therefore, consideration of effective risk management is important for the bank's financial stability, the soundness of its business, its charter, and its value and profitability.

\footnotetext{
${ }^{1}$ Note from editors: This paper was one of the three best papers selected by a review panel of three professors at the Symposium held on November 26-28, 2008, in Melbourne, Australia. The Symposium was funded by the Australian Research Council grant 20072009/10 for research on Islamic Banking and Finance.
} 
Efficiently engaging in risk management activities, as demonstrated by Mason (1995), could increase the value of the banks by reducing the chance of occurrence of costly lower tail-end in earnings and cash flows. The costly lower tail outcomes are normally associated with the likelihood of default of borrowers and the consequent costs of financial distress for a firm. This is particularly true since these costs are higher for banks as financial institutions compared to nonbank firms. Banks have the central role of creditworthiness in the provision of financial services and they assume various kinds of financial risks. Hence, the potential loss of their earnings and value could lead to high costs of default and unforeseen external financing need. These are particularly costly to the banks especially during emergency situations.

In recent years, risk management has become a bank's central activity. - The steps related to properly managing risk for ultimate savers and for the banks themselves, as proposed by Scholten and Wensveen (2003), create economic value both for the bank as well as for its clients. Accordingly, it is through the management of risk that the banks contribute to the economic welfare of the society wherein they operate.

Banks undertake risk management activities as an effort to lessen the chances of extreme fluctuations in their financial conditions. These efforts subsequently minimize the probability of becoming insolvent. A number of studies had documented the effect of various kinds of financial risks on the sensitivity of banks earnings and profitability ( Hanweck and Ryu, 2005; Saunders and Schumacher, 2000; Zarruk and Madura, 1992; Angbazo, 1997; and Wong, 1997). For instance, Hanweck and Ryu (2005) show that quarterly changes in the net interest margins (one of the main elements of bank's earnings and value) are sensitive to credit and interest rate risks of a commercial banks in different bank groups. The bank groups are defined in terms of their specializations and asset size. Their empirical tests showed that the greater the proportion of net short term assets and non-maturing liabilities of deposits that a bank holds, the more positive the effect of an increase in short term interest rate on the bank's net interest margins.

Another line of studies also supported that financial risks could lead to an adverse impact on the common stock returns of banks and accordingly would affect banks' value (Flannery and James, 1984; Scott and Peterson, 1986; Kwan, 1991; Choi, Elyasiani and Kopecky et al., 1992; Elyasiani and Mansur, 1998; Benink and Wolff, 2000; Jianping and Zheng Wang, 2000). For example, considering three different interest rate variables, Flennery and James (1984) suggested that commercial bank stock returns are very sensitive to the changes in interest rate.

From the above studies, it should be clear that banks are exposed to interest rate risk. This paper considers one of the several mechanisms that are suggested to manage the risk factor in the Islamic banks, i.e., selling murabahah on house financing to a third party in order to hedge against the movement of the market interest rates that, in turn, affects the repayments of the sum lent. 
Building on the risk management literature, this paper theoretically examines the sale of debt as a hedging strategy and its impact on the value of the Islamic banks. ${ }^{2}$

The remaining parts of this paper are presented in three sections. Section 2 provides a review of previous studies on risk management. Section 3 presents a banking model that maximizes profit from selling debt. The last section provides the conclusions.

\section{Related Literature}

Risk management in banking institutions has become more sophisticated along with the growing levels of financial risk undertaken by the banks. Banks conduct risk management in a variety of forms. Among the major sets of actions are elimination or avoidance of risks, transfer of risks, and absorption/management of risks (Allen and Santomero, 1998).

Generally banks can eliminate or avoid certain risks (i.e., systematic risk) that are not consistent with their financial characteristics by selling instruments in the spot market, hedging risk using derivatives instruments, and diversifying portfolios to minimize risk. Islamic banks, for example, allow the selling of debt created by installment sales (murabahah) and securitization of debt/asset in a way that is permitted by the shari'ah (Chapra and Khan, 2000). These mechanisms as applied by the Islamic banks are part of the risk management that helps the banks to guard risk against market uncertainties. Cebenoyan and Strahan (2004) empirically test on how credit risk management in all domestic commercial banks in the US is done through active loan purchase and sales activity; and how these affect the bank's capital structure, lending, and profit. They showed that banks take advantage of the risk reducing benefits of loan sales by taking more profitable but higher risk actions along with greater financial leverage.

There are also some types of risks that can be mitigated through the technique of risk transfer. Interest rate risk, for example, can be transferred by such products as swaps or other derivatives. Brewer, Jackson and Moser (2001) showed that banking organizations that use derivatives experience more business lending than banks that do not use derivatives. Banks that use derivatives to manage interest rate risk also hold lower levels of costly capital than other banks. The Islamic banks are also exposed to the interest rate movement that can be reduced by hedging via Islamic profit rate swap.

\footnotetext{
${ }^{2}$ The market risk in murabahah on house financing exists due to the uncertain movement of market interest rate that is used as a benchmark in setting profit margin or mark-up. The Islamic banks opt to manage against this risk by selling the debt for a lump sum plus fees. Thus, they create an opportunity to economize on the use of cash and manage capital structure.
} 
Some risks, however, should be absorbed or managed at the bank level due to their unique characteristics, such as, illiquid structure, competitive advantage, or moral hazard reasons. In this case, banks are assumed to diversify and hold sufficient amount of capital in order to assure that risk is always kept at a relatively low level. Whether risk management at the bank level can maximize or enhance value of the bank will depend on the bank's competitive advantage.

Basically, risk management consists primarily of reducing earnings volatility and avoiding large losses. The modern literature on corporate finance has offered a number of suggestions as to why a firm may be interested in reducing the volatility of its value through some hedging policy. Hedging can affect the payoff of a risk-neutral firm in that some market imperfections make the firm's payoff a concave function of some state contingent variable. The rationales for the concavity of the payoff function might be related to the firm's tax schedule (Smith and Stulz, 1985; Graham and Smith, 1999), to the costs of financial distress (Smith and Stulz, 1985; Stulz, 1996), to agency costs to asymmetric information problems (DeMarzo and Duffie, 1995), to underinvestment problems (Froot Scherfstein and Stein, 1993), or to a combination of some of these factors (Leland, 1998).

Some important deviations from the perfect capital markets in the Modigliani-Miller setting that have been identified. These induce firms to care about risk management. ${ }^{3}$ The plausibility for the above explanations on various market imperfections varies, especially when the benefits of hedging and costs of risk management are taken into account. It is clear that the cost of financial distress is viewed as the most compelling reason for risk management by firms. Volatility of earnings may lead to costly bankruptcy which firms always try to avoid. Thus for that reason, some studies offer significant insight into why the banks themselves may choose low risk strategies (Marcus, 1984). There is an extensive literature dating back to Warner (1977) on costs of bankruptcy and then to Weiss (1990) that cover evidence of financial distress.

As for banks, they face the same types of bankruptcy costs as other firms and have an incentive to manage their risks (systematic and nonsystematic) prudently so that the probability of bankruptcy is minimized. Diamond (1991) showed that banking institutions have an incentive to manage risk because bankruptcy costs can be reduced and at the same time charter values of the bank can be preserved when the bank is hedged against large losses. Therefore, mastering the stability of banks' profit is a critical credibility issue, because, if the current capital structure of a bank is not strong enough, it can have financial distress costs and some additional external funding will be required. Such funding can prove costly and dangerous due to the discrete transaction costs to obtain external financing, agency costs driven by asymmetric information, and the high cost of potential future bankruptcy.

3 Modigliani and Miller (1958) suggested that in a theoretically perfect market firms should not waste their resources in managing risks because shareholders can do it more efficiently by holding a well diversified portfolio. 
In a series of papers by Froot et al. (1993; 1998), they propose a model which endogenizes distress costs. External financing is more costly than internally generated funds due to capital market imperfections. In other words, the volatility of profitability may lead to reduction in the firm's value. If firms face constraints on their internal financing, they incur either higher costs of raising external funds or higher costs of forgone investment opportunity. The more difficult it is for a bank to raise external funds, the more risk averse it behaves. Thus, risk reduction is always desirable for the risk-averse bank in the Froot Scharfstein and Stein (1998) setting. This would suggest that the optimal risk management strategy for a bank in order to maximize its value is to fully hedge all tradable risks as long as they can be hedged at little or no cost in the capital markets.

In sum, assuming that value maximization is the ultimate objective function of the Islamic or conventional banks, risk management suggests maximization of bank value through reduction of costly capital while pursuing sufficient internal funds, if available, and taking advantage of attractive investments.

\section{The Model}

We considered a banking model that has three time periods, 0,1 , and 2 . In the first two periods, the Islamic bank decides on its capital structure, and then makes investments and debt sale decisions. The last period is required to end the model by showing that the bank achieves a sound objective function in value maximization from its hedging strategy in managing their risk exposures.

\section{A. Period 0: Capital Structure and Investment Decisions}

The sources of the Islamic banks' capital can come from subordinated long-term debt and equity. Hence at $\mathrm{t}=0$ an Islamic bank decides to lend/sell a portfolio of securities (securities held-for-trading) $\mathrm{G}_{\mathrm{t}}$ to investors under repurchase agreement. Random payoff from the portfolio will be repaid to the bondholders at $\mathrm{t}=2$. For simplicity, a standard assumption is made wherein the borrowing and lending rates in the capital markets are zero.

The Islamic bank also decides on how much equity capital, E, to hold at $\mathrm{t}=0$. More specifically, the bank's decision at $\mathrm{t}=0$ is how much of its equity capital to invest in risky asset, F. This can be interpreted as extending house financing using murabahah ("cost-plus financing" or "mark-up financing") as a mode of financing. The proceeds is to be invested in riskless securities, Gs (for instance, Malaysian Government Securities (MGS) for liquidity purposes to guard against unexpected withdrawals by depositors or draw downs by borrowers (Saidenberg and Strahan, 1999). The bank also has to decide how much to hold as capital reserves. It is assumed that reserves are perfectly liquid and have a zero return. 
Both capital and investment decisions made by the bank at $\mathrm{t}=0$ are assumed to involve direct costs. Each bank is subject to the following standard quadratic cost functions model as presented in Kopecky and Van Hoose (2004). The bank's cost functions are modelled with a specific quadratic form to allow the marginal costs to increase in response to the quantities of $G s, D, F$, and $E$.

$\begin{array}{lll}\text { Government securities cost } & : & C_{G}=(g / 2) G s^{2} \\ \text { Deposit cost } & : & C_{D}=(d / 2) D^{2} \\ \text { Financing cost } & : & C_{F}=(f / 2) F^{2} \\ \text { Equity cost } & : & C_{E}=(\mathrm{e} / 2) E^{2}\end{array}$

Where $\mathrm{g}, \mathrm{d}, \mathrm{f}$, and e are the positive cost parameters associated with $C_{j}=$ bank resource costs. $G s=$ government securities, $D=$ deposits transactions, $F$ = bank financing, and $E=$ equity. With regards to minimum capital that needs to be hold, we assume that Islamic banks are required to put aside an amount of equity equal to a fraction of bank financing and fixed percentage against deposit transactions.

\section{B. Period 1: Selling Decisions}

The Islamic bank uses murabahah in a sale agreement, whereby the bank discloses the true cost of the house and then adds a mark-up (m) to sell it at an agreed price to the customer. ${ }^{4}$ However, the mark-up is determined by adding the benchmark, i.e. base financing rate plus the spread. If we set the contract at $\mathrm{t}=0$, the Islamic bank will receive a constant stream of income through the duration of contract. Therefore at $\mathrm{t}=1$, when the market base financing rate will change, the Islamic bank is exposed to interest rate risk. To hedge against the movement of market interest rate, the Islamic bank chooses to sell a fraction or all of its sale receivable (murabahah housing contract) to a third party at $\mathrm{t}=1$. The number of murabahah housing contract is given by $h$. A position of $h$ will generate a random payoff equal to $h(m-r)$, where the mark-up rate, $m$, is known at $\mathrm{t}=0$ and $r$ represents the future spot base financing rate, which is realized at $t=1$. If we sell the contract today, during the higher rate of base financing, the Islamic bank has a competitive advantage and may charge a higher mark-up that leads to more generation of income. The payoff from the selling position can then be reinvested by the Islamic bank on other lucrative projects or provide higher return to depositors at $\mathrm{t}=2$.

\footnotetext{
${ }^{4}$ Murabahah is an acceptable form of credit sale under shari'ah. Similar in structure to a rent to own arrangement, the intermediary retains ownership of the property until the loan is paid in full.
} 


\section{Period 2: Cash Flow Realization}

At $\mathrm{t}=2$, the payoffs from the riskless assets, debt selling positions, reinvestment positions, and the amount of capital raised at $\mathrm{t}=0$ by the Islamic bank are realized. It is assumed that the Islamic bank maximizes profits:

$$
\operatorname{Max} \pi=G_{t}+r_{E} E+r_{G} G s+r_{F} F+h(m-r)-r_{D} D-C_{j}
$$

subject to a balance sheet constraint:

$$
\theta F+G s+F+\alpha D=D+E
$$

where, $\theta=$ a fraction of bank financing that required to hold as capital reserve, $\alpha=$ fixed percentage against deposit transaction, $r_{G}=$ the government securities rate, $r_{L}=$ the financing rate, $r_{D}=$ the deposit transaction rate, and $r_{E}=$ required return on equity. By using current-valued Hamiltonian,

$H=\left(G_{t}+r_{E} E+r_{G} G s+r_{F} F+h(m-r)-r_{D} D-C_{j}+\lambda(\theta F+G s+F+\alpha D-D-E)\right.$

or $\quad \mathrm{H}=(\pi)+\lambda(\mathrm{k})$

from equation (7), we can have the following optimality conditions:

$\delta \pi / \delta G t=1$

$\delta \pi / \delta G s=r G-g G s+\lambda$

$\delta \pi / \delta E=r E-e E-\lambda$

$\delta \pi / \delta F=r F-f F+\lambda \theta+\lambda$

$\delta \pi / \delta D=-r D-d D+\lambda \alpha-\lambda$

$\delta \pi / \delta h=m-r$

It follows that

$$
\begin{aligned}
& \delta h / \delta G t=m-r \\
& \delta h / \delta G s=m-r / r G-g G s+\lambda \\
& \delta h / \delta E=m-r / r E-e E-\lambda \\
& \delta h / \delta F=m-r / r F-f F+\lambda \theta+\lambda \\
& \delta h / \delta D=m-r /-r D-d D+\lambda \alpha-\lambda
\end{aligned}
$$


Equation (15) - (19) expresses the rate of change in $h$ with respect to $G t, G s, E, F$, and $D$ accordingly. The increase or decrease in $G t, G s, E, F$ and $D$ depends on the value of $m$ and $r$. During the high rate of interest, $m$ will also rise along with $r$. Therefore, Gt, Gs, E, $F$ will also tend to increase. It can be interpreted that the Islamic bank could make a decision to restructure its investment during the high rate of interest in order to reduce its risk through debt selling; and switch the benefits or payoff from the risk management position to other potential investments in $G t, G s, E$, and $F$.

If the value of $m$ is less than $r$, equation (19) shows that the rate of change in $D$ will increase. This implies that during the low and unattractive movement in the market rate of interest, the Islamic bank prefers to hold or not to sell its murabahah housing debt to the third party and continues receiving constant stream of income from the house buyer. The result is an increase in the deposit transactions of the Islamic bank.

Consistent with Cebenoyan and Strahan (2004), we also found it optimal for the Islamic bank to reduce its risk of movement in interest rate through a debt selling process in accordance with the shari'ah principal. By using debt selling, the Islamic bank can increase its value in venturing into other lucrative investments.

\section{Conclusion}

We have shown that the Islamic banks are able to maximize their value from the sale of murabahah or debt on housing in the process of managing their risk that arises from fluctuation in interest rates. By constructing a model that considers banks' capital structure, investments, and the decision to sell debt that is open to exposure due to interest rates fluctuations, we have shown that the payoff from the debt selling decision enables the bank to generate additional income. The value of the Islamic banks could further be enhanced from the risk reducing benefits of risk management, if they adopt more profitable projects or activities.

Future research may use an expanded framework of the Islamic bank models that include debt-based and equity-based (i.e. mudharabah and musharakah) financing contract together in the bank's maximization model. This would enable us to analyse the cash flow realization of the Islamic banks when implementing the appropriate hedging strategy to manage risk associated with both types of financing.

Author information: Submitting author Karmila Hanim Kamil, Universiti Kebangsaan Malaysia, Bangi, 43000 Selangor, Malaysia; Fax: +603-8921 5789, e-mail: agibab@ukm.my Abdul Ghafar Ismail is Professor of Financial Econometrics at the same university. 


\section{References}

Allen, F., and Santomero, A.M. (1998). The theory of financial intermediation. Journal of Banking and Finance 21, 1461-1485.

Angbazo, L. (1997). Commercial bank net interest margins, default risk, interestrate risk, and off-balance sheet banking. Journal of Banking and Finance, 21(1), 55-87.

Benink, H. and Wolff, C. (2000). Survey data and the interest rate sensitivity of US banks stock returns. Economic Notes, 29(2), 201-213.

Brewer, E III, Jackson, W.E and Moser, J.T. (2001). The value of using interest rate derivatives to manage risk at U.S. banking organizations. 3Q Economic Perspectives, Federal Reserve Bank of Chicago, 49-66.

Cebenoyan, A.S. and Strahan, P.E. (2004). Risk management, capital structure and lending at banks. Journal of Banking and Finance, 28, 19-43.

Chapra, M.U and Tariqullah Khan, (2000). Regulation and supervision of Islamic Banks Jeddah. Islamic Research and Training Institute, Islamic Development Bank.

Choi, J., Elyasiani, E. and Kopecky, K. (1992). The sensitivity of bank stock returns to market, interest and exchange rate risks. Journal of Banking and Finance, 16, 983-1004.

DeMarzo, P., and Duffie, D.,(1995). Corporate incentives for hedging and hedge accounting. Review of Financial Studies, 8, 743-771.

Diamond, D., (1991). Monitoring and reputation: The choice between bank loans and directly placed debt. Journal of Political Economy, 99, 689-721.

Elyasiani, E. and Mansur, I. (1998). Sensitivity of bank stock returns distribution to changes in the level and volatility of interest rate: A GARCH-M model. Journal of Banking and Finance, 22, 535-563.

Flannery, M. and James, C. (1984). The effect of interest rate changes on the common stock returns of financial institutions. Journal of Finance, 39, 1141-1153.

Froot, K. A., Scharfstein, D.S. and Stein, J.C., (1993). Risk management: coordinating corporate investment and financing policies. Journal of Finance, 48, 1629-1658.

Froot, K. A., Scharfstein, D.S. and Stein, J.C., (1998). Risk management: Capital Budgeting and capital structure policy for financial institutions: An integrated approach. Journal of Financial Economics, 47, 55-82.

Graham, J.R. and C.W. Smith, Jr., (1999). Tax incentives to hedge. Journal of Finance, 54, 2241-2262.

Hanweck, G. and Ryu, L., (2005). The sensitivity of bank net interest margins and profitability to credit, interest rate, and term-structure shocks across bank product specializations. Working Papers, School of Management, George Mason University.

Jianping, M. and Wang, Z. (2000). Excess risk premia of Asian Banks. International Review of Finance, 1(2), 143-159. 
Kopecky, K.J., VanHoose, D. (2004). A model of the monetary sector with and without binding capital requirements. Journal of Banking and Finance, 28, 633-646.

Kwan, S. (1991). Re-examination of interest rate sensitivity of commercial bank stock returns using a random coefficient model. Journal of Financial Services Research, 5, 61-76.

Leland, Hayne E., (1998). Agency costs, risk management, and capital structure, Journal of Finance, 53(4), 1213-1243.

Mason, S.P. (1995). The Allocation of Risk. Working Paper 95 - 060. Harvard Business School.

Marcus, Alan J., (1984). Deregulation and Bank Financial Policy. Journal of Banking and Finance, 8, 557-65.

- Modigliani, F. and Miller, M. H. (1958). The cost of capital, corporate finance and the theory of investment. American Economic Review, 48, 261-97.

Saidenberg, M.R., Strahan, P.E., (1999). Are banks important for financing large businesses? Current Issues in Economics and Finance, 5(12), 1-6.

(1) Saunders, A. and Schumacher, L. (2000). The determinants of bank interest rate margins: An International Study. Journal of International Money and Finance, 19(6), 813-832.

Scholten, B. and Wensveen, D. (2003). The theory of financial intermediation: An essay on what it does (not) explain. The European Money and Finance Forum. SUERF Vienna.

Scott, W. and Peterson, R. (1986). Interest rate risk and equity values of hedged and unhedged financial intermediaries. Journal of Financial Research, 9, 325-329.

Smith, Jr., C.W. and Stulz, R.M., (1985). The determinants of firms' hedging policies. Journal of Financial and Quantitative Analysis, 20, 391-405.

Stulz, R.M., (1984). Optimal hedging policies. Journal of Financial and Quantitative Analysis, 19, 127-140.

Stulz, R.M., (1996). Rethinking risk management. Journal of Applied Corporate Finance, 9, 8-24.

Warner, J., (1977). Bankruptcy costs: Some evidence. Journal of Finance, 32 337-347.

Weiss, L., (1990). Bankruptcy resolution: direct costs and violation of priority of claims. Journal of Finance and Economics, 27, 285-314.

Wong, K.P. (1997). On the determinants of bank interest margins under credit and interest rate risks. Journal of Banking and Finance, 21(2) 251-271.

Zarruk, E. and Madura, J. (1992). Optimal bank interest margin under capital regulation and deposit insurance. Journal of Financial and Quantitative Analysis, 27(1) 143-149. 